\title{
Effectiveness of Green Open Space Regulation in Badung District
}

\author{
Adrianus Hukapati Simon Nahak ${ }^{1}$, I Ketut Widia ${ }^{2}$, Umar Ibnu Alkhatab ${ }^{3}$ \\ \{Simonnahak1964@mail.com ${ }^{1}$ \} \\ Magister of Law, Universitas Warmadewa, Denpasar, Indonesia
}

\begin{abstract}
There is a difference between the Regional Regulation of Badung Regency Spatial Plan and Badung Regency Green Path Regional Regulation concerning the establishment of green path areas in Badung Regency. In this study two issues were discussed, those are the effectiveness of the regulation regarding the path area in Badung Regency and the effort of Badung Regency government in upholding the green path area in Badung Regency? This type of research is empirical legal research because there are gaps between das sollen and das sein. The approach used is the fact approach, legislative approach, case approach. In conclusion, the effectiveness of the regulation regarding the green path area in Badung Regency of Badung Regency Government is not yet effective. Due to the establishment of illegal buildings along the green open space area in Badung Regency and not in accordance with Badung District Regulation Number 26 of 2013 concerning Badung Regency Spatial Plan for 2013-2033 (Regional Regulation of Badung Regency Spatial Plan). The efforts of Badung Regency government in upholding the green path area in Badung Regency are by implementing legal, administrative systems that include interactions between various law enforcement officers who are sub-judicial systems in the form of administrative actions and enforcement of Green Path Regions.
\end{abstract}

Keywords: Effectiveness, Arrangement, Green Path, Badung Regency

\section{Introduction}

The definition of Green Open Space is in Badung District Regulation Number 26 of 2013 concerning Badung Regency Spatial Plans for 2013-2033 Article 1 number 38 that is "Green Open Space, hereinafter referred to as GOS, is a longitudinal/path area and/or in group, which use is more open, which plants grow, both naturally grown and intentionally planted ".

In an urban area, there are four functions of open green space that are combined in accordance with the needs, interests and sustainability of the city, those are:

1) The main function is to guarantee the procurement of open green space as part of the air circulation system (city lungs), micro-climate regulators so that the air and water circulation systems naturally can run smoothly, like shade, oxygen producers, rainwater absorbers, wildlife habitat providers, absorbing pollutants in air, water and soil media, as well as windbreaks.

2) Social and cultural functions, that is describing the expression of local culture, which is as communication media for the citizens of the city, places of recreation, places and objects of education, research, and training in studying nature. 
3) Economic function that is the source of products that can be sold, such as flowers, fruit, leaves, vegetable major and can be part of the business of agriculture, plantation, forestry and others.

4) The aesthetic function, that is enhancing comfort, beautifying the city environment both from the micro scale such as the yard, residential environment, and macro scale, that is the landscape of the city as a whole, stimulates creativity and productivity of city residents, forming architectural beauty factors, creating a harmonious and balanced atmosphere between the building area and non-building area.

Regarding to determination of the green path area according to the Regional Regulation of Badung Regency Spatial Plan, there are only 5 sub-districts, while there are 13 departments in the determination of the green lane area according to the Green Path Regional Regulations in Badung Regency. Moving on from the assumptions regarding the enactment of a regulation in terms of Badung Green Path Regional Regulation that is promulgated on May $17^{\text {th }}, 1993$ with the Regulations of Spatial Plans Badung Regency that is promulgated on December $30^{\text {th }}, 2013$ with a time difference of 247 months or 20 years 7 months have shrunk much of the green path area in Badung Regency. The following description is explanation of some previous research related to the current issue. Firstly, a research carried out by [1]. The study focuses on the factors that influence the production of green patents as a proxy of new "environmental" knowledge for a panel of European countries over time. The results showed that both markedbased regulation policies and participation in green European research networks (in particular with universities and public research centres) positively affect environmental innovation. Moreover, the two policy tools have a complementary effect. This suggests that the effectiveness of environmental regulation policies can be increased by combining them with appropriate innovation policies.

Secondly, a research conducted by [2], the results were, among the antecedents of the green innovation analyzed, the rigor of the environmental regulations of the countries and the size of the companies had a statistically significant positive impact of the industrial enterprises of the MEDC and LEDC only in the IV2 construct, composed of the variables Global Compact and environmental investments. The competitiveness of the countries did not have a positive influence on the GI effort of the companies, and the Degree of Internationalization of companies has not had a significant effect on any of the GI constructs. Moreover, the results also showed that the relationship between environmental regulation and GI is moderated positively by the size of the companies and moderated negatively by the degree of internationalization, and the relation between the competitiveness of the countries and GI is negatively moderated by the size of the companies and moderated positively by its degree of internationalization. Thirdly, a research done by [3]. This study focuses on analysis of the ability of Urban Green Spaces to promote adaptation to climate change for both risk control and as an urban regeneration resource. With the analysis of two urban regeneration cases studied in zones affected by climate change, Red Hook in New York and Zorrotzaurre in Bilbao, the adaptation policies in the United States and Europe are studied. These cases allow a focus on how cities' capacities to establish initiatives for specific adaptation measures include Urban Green Spaces. Final conclusions reveal that, according to the extreme events expected, location and composition of Urban Green Spaces is key in the adaptive strategy of cities facing climate change. From the description of the background above, the problem can be formulated such as what is the effectiveness of the regulation regarding areas of green open space in Badung Regency? And what are the efforts of Badung Regency Government in upholding green open space areas in Badung Regency? 


\section{Literature Study}

The Literature Review discusses the conceptual basis used in a study which aims to direct the researcher variable or title and apply theories that will be used to support the main points of discussion and obedience to different interpretations of the theoretical framework used in formulating concepts with by using definition. The theoretical basis used is Authority Theory according to [4], State Law Theory according to [5], and Theory of Legal Effectiveness according to Soerjono Soekanto.

\section{Methods}

The type of research used in this study is by using empirical legal research type or socio-legal research type. Which is this research departs from the gap between das solen and das sein, that is the existence of a gap between theoretical conditions and legal facts that occur in society.

The empirical research is known to 7 (seven) types of approaches, they are:

a) The Case Approach

b) The Statute Approach

c) The Fact Approach

d) The Analytical \& Conceptual Approach

e) The Phrase Approach (Word \& Phrase Approach)

f) Historical Approach

g) Comparative Approach.

The source of Legal Material can be divided into 3, they are primary legal material, secondary legal material, tertiary legal material. The data collection techniques used in this study is document study techniques, interview techniques, and direct observation techniques.

\section{Results And Discussion}

\subsection{The Effectiveness of Arrangement in Green Open Space Area in Badung District}

The definition of Government in the broadest sense is all matters carried out by the state in carrying the state life. So it is not interpreted as a government that only carries out legislative and judicial functions. Whereas a government in the narrow sense is the implementation of executive functions from the state which in this case can be carried out by the President or the Prime Minister to the lowest level, such as the Village Head.

The government comes from a command word which means to do something. So that it can be said that the government is the power to govern a state or the highest body that governs a state such as a cabinet which is as a government. This is a different term of government which is defined by the actions. The government as a state apparatus can be interpreted broadly (in the broad sense) and in a narrow sense. The government in the broad sense includes all state equipment, which basically consists of branches of executive, legislative, and judicial power or other states [6] which is act for and on behalf of the state, whereas in a narrow sense the government is a branch of executive power. Indonesian Law State requires 
harmonious relations between the government and the people who set in harmony. According to [7], the important elements of Indonesian legal state are:

1) The harmony of relations between the government and the people based on the principle of harmony;

2) The proportional functional relations between state powers;

3) The dispute resolution in deliberation and justice is the last means if the deliberation fails and the balance between rights and obligations.

So that in the embodiment of the state of law Indonesia lies only on the basis of reliance, that is the balance of relations between the government and the people. The granting of regional governments authority to organize their government is carried out through a process called decentralization to autonomous regions, also known as regional autonomy. Decentralization has two forms, they are political and administrative.

Political decentralization is the authority to make decisions and do a certain control over resources given to local and regional governments. Administrative decentralization is a delegation of implementation authority given to central officials at the local level. Its authority starts from setting regulations to substantial decisions. The implementation of the principle of responsible regional autonomy means that the granting of regional autonomy is truly in accordance with its objectives, [8] those are

1) The smooth and orderly development in all regions of the state;

2) whether the development in all regions of the state are in accordance or not;

3) In accordance with political development and national unity;

4) The guaranteed harmony of relations between the central government and the regional government; and

5) Guaranteed development and regional development.

The purpose of building green open space as a green infrastructure in urban areas is to improve the quality of urban environments that are comfortable, fresh, beautiful and clean, as a means of urban environment; creating harmony between the natural environment and the built environment that is useful for the benefit of the community; and create a city that is healthy, livable, and sustainable. The objective of structuring green open spaces in urban areas is contained in Article 2 of the Minister of Home Affairs Regulation Number 1 of 2007 concerning the Arrangement of Green Open Spaces in Urban Areas.

a) Maintain the confidentiality and balance of urban ecosystems;

b) Realizing a balance between the natural environment and the artificial environment in urban areas;

c) Improve the quality of a healthy, beautiful, clean and comfortable urban environment.

When reviewing further, Badung Regency Government has two legal bases regarding green open space that is Badung District Regulation Number 26 of 2013 concerning Badung Regency Spatial Plan for 2013-2033 (Spatial Plans Regional Regulation of Badung Regency) and the Regional Regulation of the Level II Badung Regency Number 3 of 1992 concerning Prohibition of Building Construction in Regions of Green Open Space in Level II of Badung Regency (Green Open Space Regional Regulation of Bungung Regency).

The sustainability of development in an area or country is determined by the ability of the region or state in managing its environment. The approach to environmental management is done by managing the management system. The article 14 Environmental Protection and Management Law states that the instruments for preventing pollution and environmental damage are basically also instruments of environmental management because life management is also intended to prevent and overcome problems of pollution and environmental damage.

The instruments in Article 14 of Environmental Protection and Management Law are: 
1) Strategic Environmental Assessment;

2) Layout;

3) Environmental quality standards;

4) Environmental quality criteria;

5) Environmental Impact Analysis;

6) Environmental Management Efforts and Environmental Monitoring Efforts;

7) Licensing;

8) Economic instruments;

9) Environmental-based legislation;

10) Environment budget;

11) Environmental based analysis;

12) Environmental audit.

Management in Law Number 32 of 2009 followed by the word "protection", in which environmental protection and management demand the development of an integrated system in the form of a national policy on environmental protection and management that must be carried out in a consistent and consistent manner from the centre to region. Therefore, Indonesia's environment must be protected and managed properly based on the principle of state responsibility, sustainability, harmony, balance, integration, benefits, prudence, justice, ecoregion, biodiversity, paying polluters, participation, local wisdom, good governance, and regional autonomy. The effectiveness of the application of the Regional Regulation of Spatial Plans Badung Regency and Regional Regulation of Green open space Badung Regency has been enforced properly, but there are still many violations of the green open space area and the role of the community that is not optimal. So far in the process of law enforcement carried out by the Civil service police Unit Badung Regency which obtained authority based on the law (attribution). Referring to [9] of view that law enforcement is determined by how effectively law enforcement officers are able to carry out enforcement procedures, and if it is related to law enforcement provisions in the Regional Regulation, the substance of the Regulations of Badung District Spatial Planning with the Regional Regulations Green open space of Badung Regency has not provided certainty because each governs the area of green open space.

\subsection{The Government of Badung District Effort in Enforcing The Green Open Space Area In Badung District}

The concept of the state of modern law/material (welfare state) adopted by Indonesia, with the aim of the realization of a just and prosperous society both spiritually and materially based on Pancasila and the 1945 Constitution; so that it is called the state of Pancasila law. In such a legal state, the functions/duties of the Indonesian state are as follows:

a) Security, defence and order functions (defence, security, and protection functions). Included in this function are functions of protection of life, property rights, and other rights in accordance with those stipulated in legislation.

b) Welfare function, including social service and social welfare. What is clear is that all activities aimed at the realization of community welfare and social justice for all Indonesian people.

c) Educational functions, including the tasks of general illumination of nation and character building, increasing culture and so on.

d) The function of achieving world order and prosperity (world peace and human welfare) in the broadest sense. 
Thus, in Indonesian legal state based on Pancasila and the 1945 Constitution, there is a balance and integration of regular functions and development functions. State Welfare is a State concept that aims to prosper the citizens. The Government's duty in the concept of the State of the welfare state is no longer limited to night guards but must actively participate in community activities so that the welfare of all people is guaranteed. Thus the Government must provide protection for its citizens not only in the political sphere but also in the socio-economic field, so that arbitrariness from the rich must be prevented by the Government [10]. According to [11], when the government carries out public legal actions, it uses the authority given by legislation, therefore its actions are always unilateral. However, if the authorization contains freedom or "Ermessen freedom/discretionary power", the government can utilize its authority by using a cooperation mechanism (cooperation). So it can be said that every legal action of the government is subject to juridical boundaries. The government actions with any juridical instruments used must remain within the legal/statutory corridor and directed towards realizing general welfare, in accordance with the beginning of the emergence of the concept of the modern law state (welfare state). Muchsan mentioned several elements of government action as follows:

1) The act is carried out by government officials in their positions as rulers and as government tools with their own initiatives and responsibilities.

2) The act is carried out in order to carry out the functions of government.

3) The act is intended as a means to cause legal consequences in the field of administrative law.

4) This action concerns the maintenance of the interests of the state and the people.

5) The act must be based on applicable laws and regulations.

In Article 144 of the Regulations of Badung Regency Number 6 of 2009 Concerning the Spatial Plans of Badung Regency, it has granted criminal sanctions against violations of green open spaces. So that the Badung Regency government, in this case, can take firm action against violators of green open space in Badung Regency and has fulfilled the Government's Action Elements including [11].

1) The act is carried out by government officials in their positions as rulers and as government tools with their own initiatives and responsibilities.

2) The act is carried out in order to carry out the functions of government.

3) The act is intended as a means to cause legal consequences in the field of administrative law.

4) This action concerns the maintenance of the interests of the state and the people.

5) The act must be based on applicable laws and regulations.

\section{Conclusion}

Firstly, regulations regarding the area of green open space in Badung Regency have not been effective. This happened because there were still unlicensed buildings built along the green open space area in Badung Regency and not in accordance with the Badung District Regulation Number 26 of 2013 concerning the Badung Regency Spatial Planning for 2013-2033 (Regional Regulation). The spatial plans of Badung 
Regency and Badung District Level Regional Regulation Number 3 of 1992 concerning Prohibition of Building-Construction in Green Open Space Areas in Badung Regency Level II (green open space regional regulation of Badung district). Secondly, The efforts of the Badung Regency government in upholding green open space areas in Badung Regency are by enforcing the law, an administrative system that includes interactions between various law enforcement agencies which are subjudicial systems in the form of administrative actions and government actions in enforcing the Area green open. This is governed by Article 144 of the Badung Regency Perda Number 6 of 2009 concerning the Spatial plans of the Badung Regency which imposes criminal sanctions on Violations of Green Open Space.

\section{References}

[1] A. Fabrizi, G. Guarini, and V. Meliciani, "Green patents, regulatory policies and research network policies," Res. Policy, vol. 47, no. 6, pp. 1018-1031, 2018.

[2] J. M. L. S. Borsatto and L. B. L. Amui, "Green innovation: Unfolding the relation with environmental regulations and competitiveness," Resour. Conserv. Recycl., vol. 149, no. June, pp. 445-454, 2019.

[3] F. García Sánchez, W. D. Solecki, and C. Ribalaygua Batalla, "Climate change adaptation in Europe and the United States: A comparative approach to urban green spaces in Bilbao and New York City," Land use policy, vol. 79, no. November 2017, pp. 164-173, 2018.

[4] P. Atmosudirdjo, Hukum Administrasi Negara. Jakarta: Ghalia Indonesia, 1981.

[5] P. M. Hadjon, Pengantar Hukum Administrasi Indonesia. Yogyakarta: Universitas Gadjah Mada Press, 2005.

[6] H. Cipto and Y. Theresjanti, Fundamentals of Indonesian Constitutional Law. Yogyakarta: Atmajaya University, 2000.

[7] P. M. Hadjon, Introduction to Indonesian Administrative Law. Yogyakarta: Gadjah Mada University Press, 2005.

[8] B. Manan and K. Magnar, Several Indonesian Constitutional Legal Issues. Bandung: Alumni, 1997.

[9] L. M. Friedman, The Legal System for Social Science Perspective. New York: Russel Sage Foundation, 1975.

[10] Muchsan, Oversight System Against the Actions of Government Officials and State Administrative Courts in Indonesia. Yogyakarta: Liberty, 2000.

[11] R. H.R., Hukum Administrasi Negara. Jakarta: PT. Raja Grafindo, 2006.

[12] Regional Regulation of Badung Regency Number 26 of 2013 concerning Badung Regency Spatial Planning 2013-2033;

[13] Regional Regulation of the Level II of Badung Regency Number 3 of 1992 concerning Prohibition of Building and Construction in the Area of Green Open Space in Level II of Badung Regency.

[14] Joy Irman, 2014, "Room Arrangement", URL: http://www.penataanruang.com/ruang-terbukahijau.html accessed on December 5, 2018 at 10.00 WITA 